RUTMech, t. XXXIII, z. 88 (4/16), październik-grudzień 2016, s. 379-387

\author{
Lucjan WITEK ${ }^{1}$ \\ Feliks STACHOWICZ ${ }^{2}$
}

\title{
THERMO-MECHANICAL STRESS ANALYSIS OF THE TURBINE OF HELICOPTER ENGINE
}

\begin{abstract}
In this paper the results of the numerical stress analysis of the power turbine of helicopter engine were presented. In order to solve the problem, the nonlinear finite element method was used. The numerical models of both the blade and the disc segment were made using the MSC-Patran program. In the analysis the thermal load resulting from non-uniform temperature field was defined. The centrifugal force resulting from the rotation of the engine rotor was also considered. The cyclic symmetry boundary condition of the disc segment was used to decrease the size of the numerical task. The model of the turbine material was defined as linear-elastic. The modulus of elasticity and the thermal expansion coefficient of the disc and the blade material were considered as temperature dependent. As a result of performed computations, the stress distributions for the turbine subjected to both the thermal and the mechanical loads were determined.
\end{abstract}

Keywords: aero-engine, turbine blade, rotor disc, thermo-mechanical stress analysis, finite element method

\section{Introduction}

Gas turbine discs and blades (Figs. 1, 2a) are usually the most critical engine components, which must endure substantial mechanical and thermal loads. The turbine has three critical regions on which attention should be focused: fir tree slots, the assembly holes and the hub zone. The joint between the turbine blade and the disc usually represents the most critical area from the point of view of the static and fatigue strength. The loads associated with these regions are mainly the centrifugal forces and the thermal stresses [1-3].

The stress and strain analysis of the turbine discs and blades was described in the papers [4-5]. In many cases the complex shape of the disc-blade connection caused that only in this region the stress concentration factor has large values. A large centrifugal force of the blade causes that the maximum

${ }^{1}$ Autor do korespondencji/corresponding author: Lucjan Witek, Rzeszow University of Technology, Al. Powstańców Warszawy 12, 35-959 Rzeszów, Poland, e-mail: lwitek@prz.edu.pl

${ }^{2}$ Feliks Stachowicz, Rzeszow University of Technology, e-mail: stafel@prz.edu.pl 
stress area is often located in the internal radius of the fir tree slots of the disc and the blade [6].

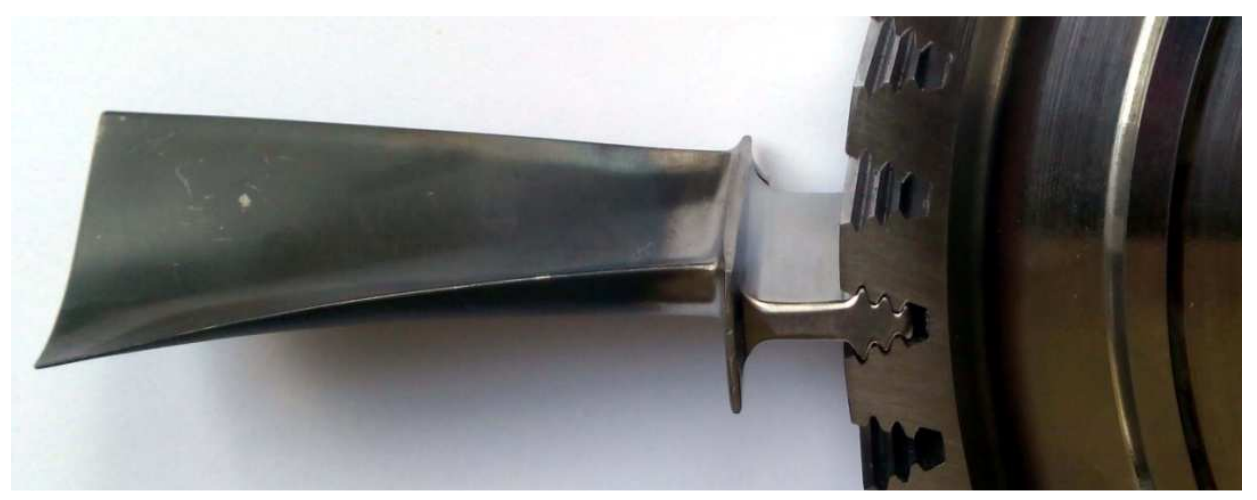

Fig. 1. View of the turbine blade and the fragment of the disc with fir tree slots

The main aim of this work is determination of the stress state in the power turbine of the helicopter engine subjected to the complex thermomechanical load. The thermal stress (as a result of thermal field remaining by certain time in the turbine components) occurs after turning off the engine. Therefore, in this work a separate thermal stress was also determined for the turbine without the mechanical loads.

\section{Numerical model of turbine}

The geometrical models of the disc and the blade were made using the MSC-Patran program (Fig. 2 b, c) [7]. The FE model of the turbine (Fig. 2d) consists of 100280 nodes and 507836 TET-4 solid elements. In the analysis two kinds of loads were considered: the speed of rotation of the turbine (22490 RPM) and the non-uniform temperature field. The centrifugal forces were computed by definition of the following parameters: the blade and disc material density, the speed of rotation and the position of rotation axis. The power turbine of the analyzed engine is composed of the disc and 51 blades. In order to decrease the size of the numerical task, the segment of the disc consisted of 1/51 part of all structure was considered with the use of the special cyclic-symmetry boundary condition [8]. In this condition the stress and displacement components (in the cylindrical coordinate system) defined on the left and right (virtual) surfaces of the disc segment are the same.

The nodes on the rotation axis of the turbine disc (bottom part of the disc presented in Fig. 2c) were partially fixed (translations $T_{x}=0, T_{y}=0$ ). For one central node located on the rotation (symmetry) axis of the disc the full fixation was applied $\left(\mathrm{T}_{\mathrm{x}}=0, \mathrm{~T}_{\mathrm{y}}=0, \mathrm{~T}_{\mathrm{z}}=0\right)$. 


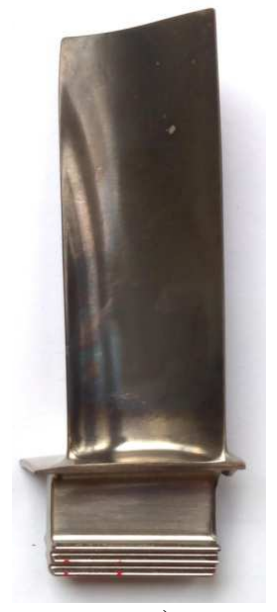

a)

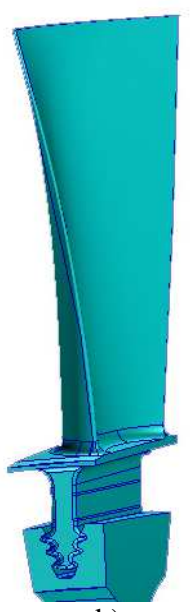

b)

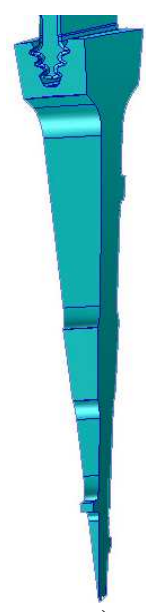

c)

d)

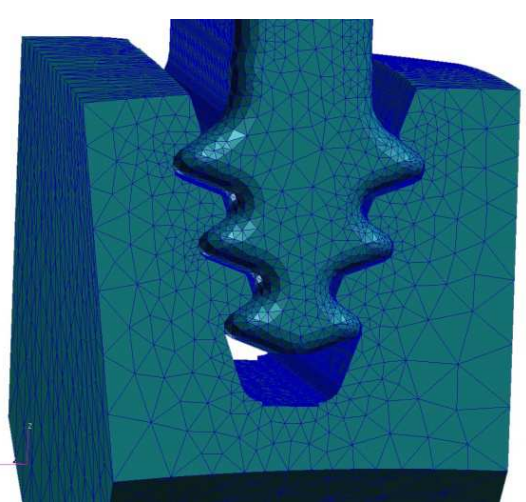

Fig. 2. View of the real blade - object of investigations (a). Geometrical model of the turbine blade (b) and the disc segment (c). Finite element mesh in the vicinity of fir tree slots (d)

The maximum temperature zone $\left(588^{\circ} \mathrm{C}\right)$ was located on the top part of the blade (Fig. 3). In the fir tree slot of the turbine the temperature value is about $400^{\circ} \mathrm{C}$ whereas in the middle part of the disc (in the vicinity of rotation axis) the temperature is much lower $\left(180^{\circ} \mathrm{C}\right)$. The temperature field was defined for the engine power of $890 \mathrm{HP}$ (horsepower) and for the work of the engine at an altitude of $2500 \mathrm{~m}$. In the fir tree surfaces of the disc and the blade the Coulomb contact "master-slave" [8] with the friction coefficient of 0.05 was defined. The nonlinear stress analysis was performed using Abaqus solver [8]. The disc and the blade were made of EI-437-b alloy. EI-437-b nickel alloy has a good creep resistance and was used for rotational components of the turbine engines operated at high temperature. Yield stress (YS) 
and the ultimate tensile strength (UTS) of EI-437-b alloy measured at high temperature are presented in Figure 4 [9].

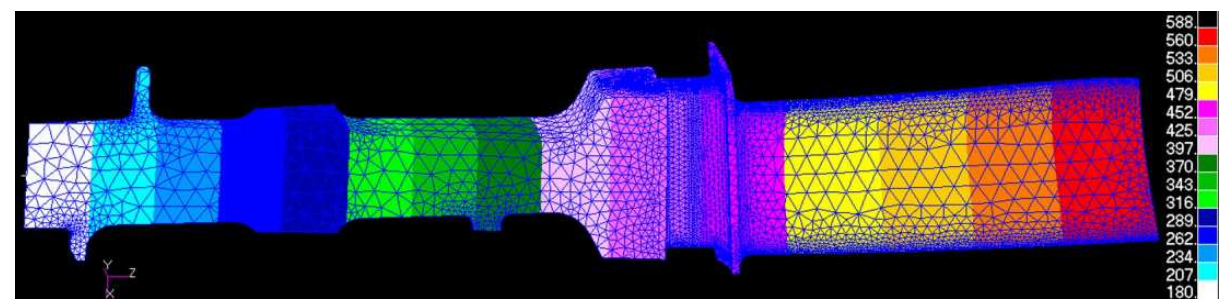

Fig. 3. Temperature field defined for turbine segment (condition of engine work: altitude of $2500 \mathrm{~m}$, engine power of $890 \mathrm{HP}),{ }^{0} \mathrm{C}$

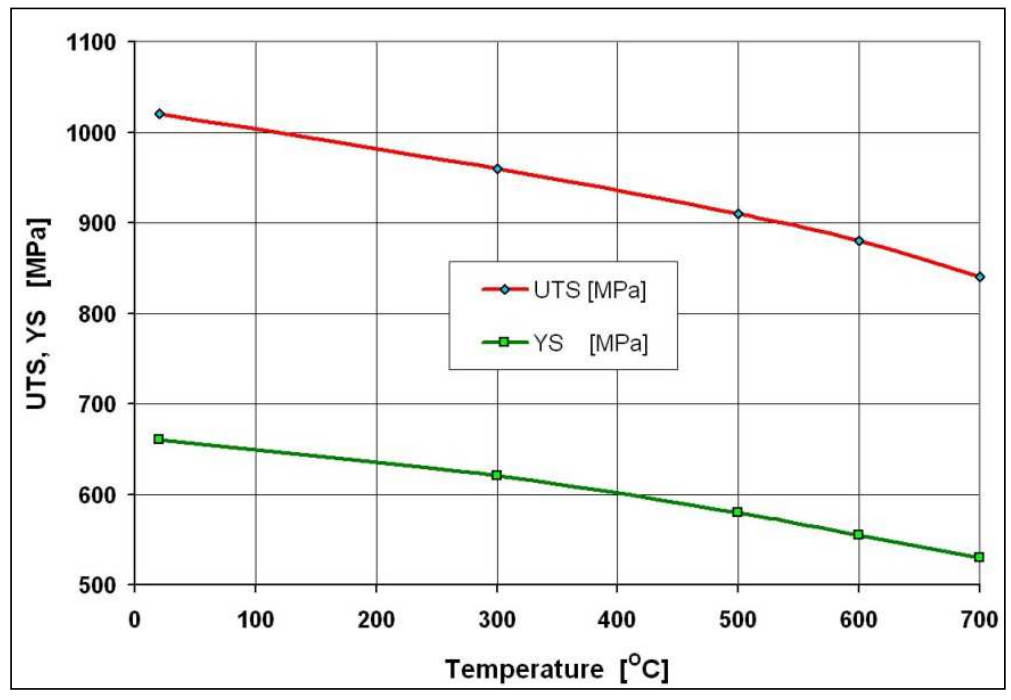

Fig. 4. Ultimate tensile strength (UTS) and yield stress (YS) of EI-437-b alloy as a function of temperature

The blade and disc material density is equal to $8200 \mathrm{~kg} / \mathrm{m}^{3}$ (at room temperature). The thermal expansion coefficient $(\alpha)$ and Young's modulus (E) for EI-437-b alloy were considered as a temperature dependent (Tab. 1) [9].

Table 1. Values of thermal expansion coefficient and Young's modulus at high temperature for EI-437-b alloy [9]

\begin{tabular}{|c|c|c|}
\hline $\begin{array}{c}\text { Temperature } \\
{ }^{0} \mathrm{C}\end{array}$ & $\begin{array}{c}\text { Young's modulus } \\
\mathrm{E} \times 10^{5}, \mathrm{MPa}\end{array}$ & $\begin{array}{c}\text { Thermal expansion coefficient } \\
\alpha \times 10^{-5}, 1 /{ }^{0} \mathrm{C}\end{array}$ \\
\hline 200 & 2.00 & 1.27 \\
\hline 400 & 1.95 & 1.75 \\
\hline 600 & 1.66 & 1.14 \\
\hline 800 & 1.01 & 1.51 \\
\hline
\end{tabular}




\section{Results of stress analysis}

The results of finite element analysis showed that during the work of the engine (for superposition of thermal and mechanical loads), the area of maximum reduced stress in the disc (784 MPa, Fig. 5) is located in the small zone, under the third fir tree slot. This value exceeds the yield stress of disc material at about $184 \mathrm{MPa}$ (YS of EI-437-b alloy for $400^{\circ} \mathrm{C}$ equals to $600 \mathrm{MPa}$, Fig. 4). Obtained maximum stress value is smaller than UTS of the disc material at about $170 \mathrm{MPa}$.

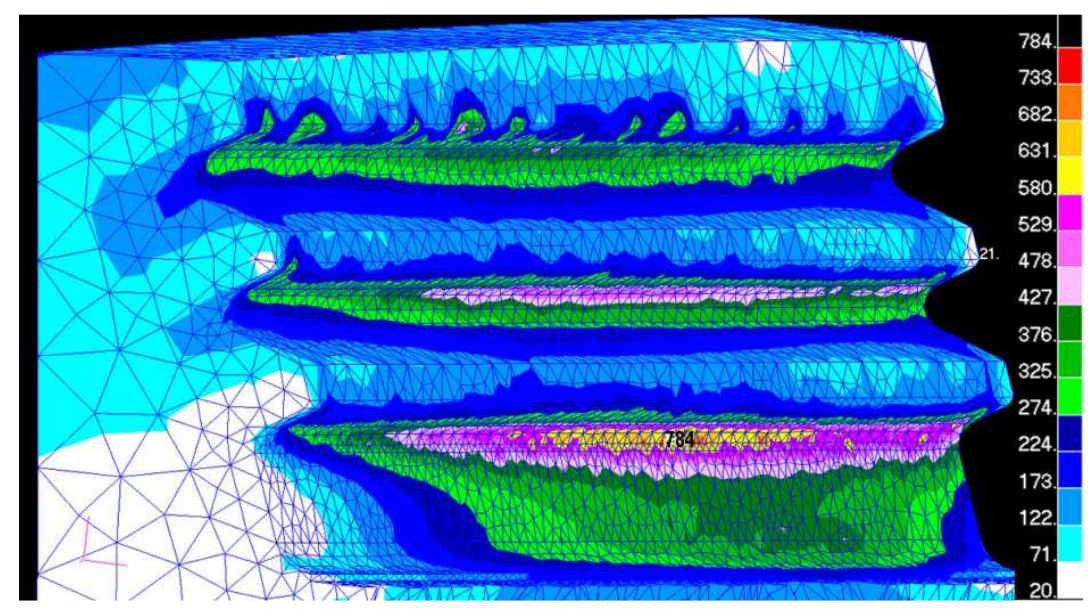

Fig. 5. Reduced (acc. to Huber-Mises-Hencky criterion) stress distribution in fir tree slots of disc as a result of coupled the mechanical and the thermal load (engine work conditions: altitude of $2500 \mathrm{~m}$, engine power of $890 \mathrm{HP}$ ), $\mathrm{MPa}$

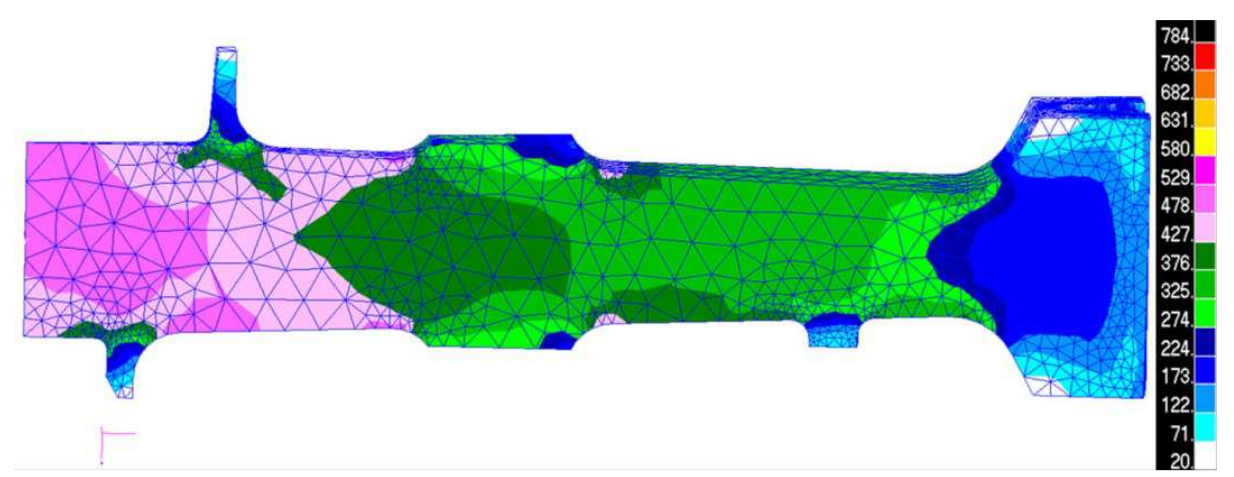

Fig. 6. Reduced (acc. to Huber-Mises-Hencky criterion) stress distribution in cross-section of the disc as a result of coupled the mechanical and the thermal load (engine work conditions: altitude of $2500 \mathrm{~m}$, engine power of $890 \mathrm{HP}$ ), MPa 
The maximum reduced stress in the blade subjected to couple the thermal and the mechanical load achieves the value of $684 \mathrm{MPa}$. Maximum stress area is located on the corner of second and third fir tree slot (Fig. 7a). This value exceeds the yield stress of the blade material (for $400^{\circ} \mathrm{C}$, Fig. 4) at about 84 $\mathrm{MPa}$. The large stress zones (456 MPa) are also located above the first (top) slot of the serration and in the bottom part of the airfoil section (Fig. 7). In the central and the top part of the blade smaller values of stresses (92-223 MPa) are observed (Fig 7b).

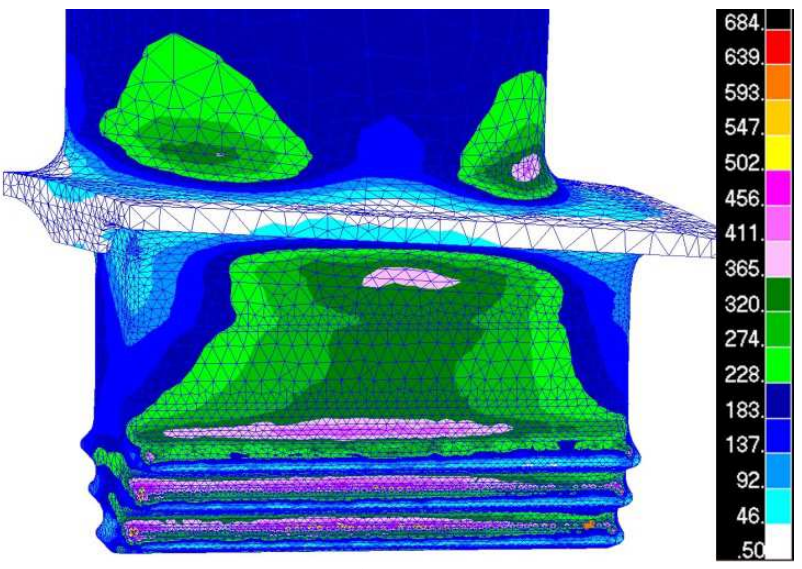

a)

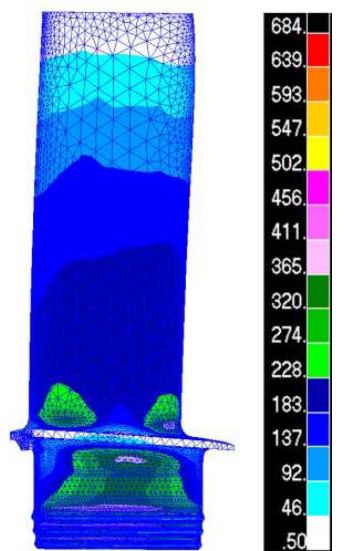

b)

Fig. 7. Reduced (acc. to Huber-Mises-Hencky criterion) stress distribution in the bottom part of the blade (a) and in the blade airfoil section (b) (coupled mechanical and thermal load, engine work conditions: altitude of $2500 \mathrm{~m}$, engine power of $890 \mathrm{HP}$ ), MPa

The centrifugal (mechanical) forces disappear after turning off the engine but the thermal field remains for a certain time. Thus, in the second load case a separated thermal load was applied to the turbine. The results of this analysis are interesting not only from a practical but also from a research point of view. The analysis of separate thermal load can provide the information about the impact of the thermal stress on the effort of material of the turbine during the work of the engine.

In the turbine subjected to the thermal load only (the non-uniform temperature field presented in Fig. 3) the reduced stress achieves the largest value of $461 \mathrm{MPa}$ on the corner of the disc, about $3 \mathrm{~mm}$ under the third fir tree slot. In the central part of the disc the thermal stress achieves the values of 124-216 MPa (Fig. 8a).

A low impact of the thermal field on the stress values in the blade is found. The maximum value of reduced stress in the central part of the blade airfoil section is equal only to $9.8 \mathrm{MPa}$ (Fig. 8b). 


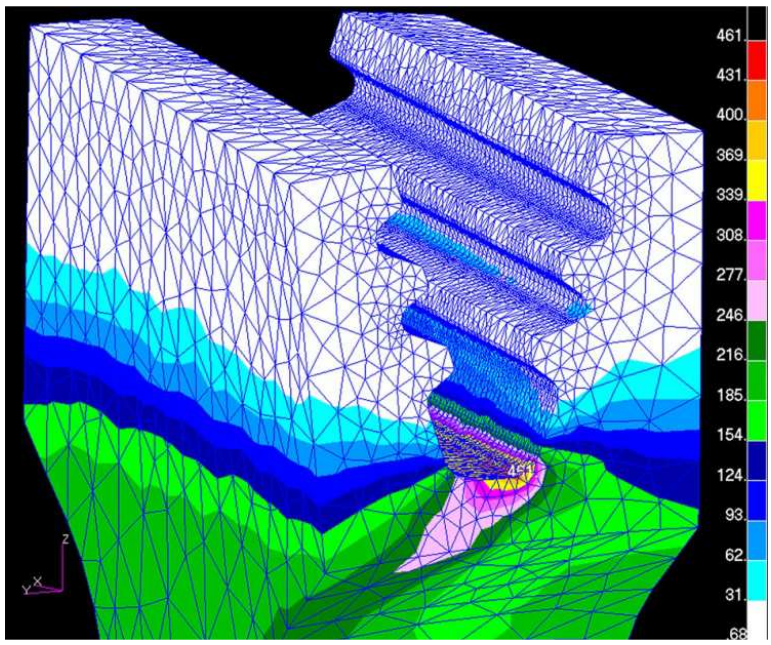

a)

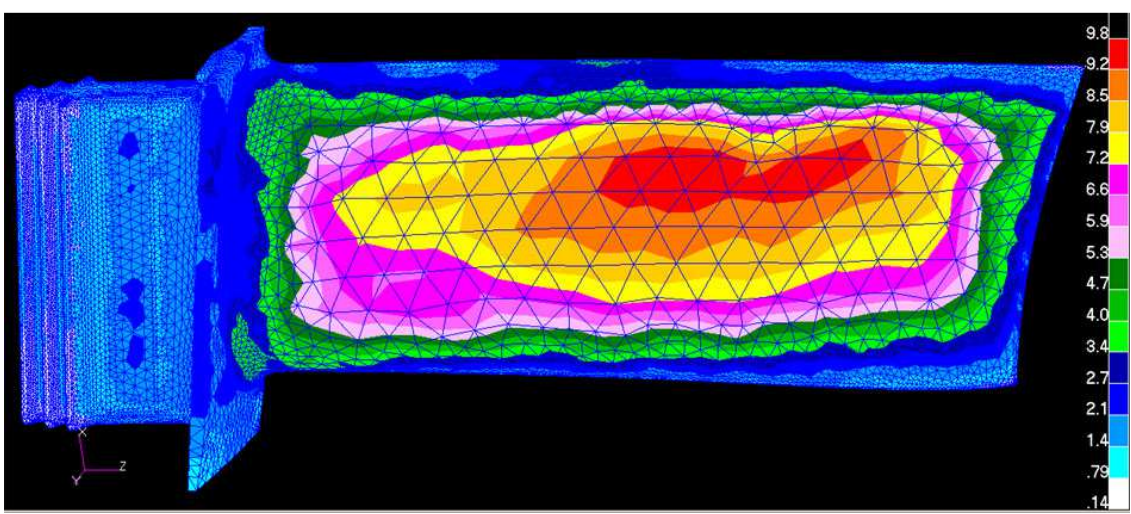

b)

Fig. 8. Reduced (acc. to Huber-Mises-Hencky criterion) stress distribution in the disc (a) and the blade (b) as a result of thermal load only, MPa

\section{Conclusions}

In this work the results of numerical stress analysis of the power turbine of helicopter engine were presented. In order to decrease the size of the numerical task, the special cyclic-symmetry boundary condition was defined. The disc segment and the blade were subjected to the complex thermomechanical load. From the simulation results, conclusions can be drawn as follows:

1. The value of maximum reduced stress $(784 \mathrm{MPa})$ in the disc subjected to couple the thermal and the mechanical loads exceeds (locally) the yield stress of the disc material at about $184 \mathrm{MPa}$. Computed stress value is 
smaller than UTS of the disc material at $170 \mathrm{MPa}$. The results of stress analysis performed for another engines showed that the local stress in the turbine fir tree slots can be higher than YS of the material $[2,10]$.

2. The large values of stresses (478-529 MPa) are also observed in the vicinity of the disc rotation axis.

3. The maximum stress in the blade subjected to thermal and mechanical load achieves (in the fir tree slot area) the value of $684 \mathrm{MPa}$. This value exceeds YS of the blade material at $84 \mathrm{MPa}$. The high stress area is often observed in the fir tree region of the blade and the disc of aero-engines [11-13].

4. It was assumed that during the first work of the engine, the zones of fir tree slots (in which the stress exceeds YS) can be locally plastified. After that the distance between the slots fir tree slots are different and during next acceleration of the engine the stresses could be lower.

5. During the thermal load only the reduced stress achieves the value of $461 \mathrm{MPa}$ in the bottom region of fir tree slot of the disc.

6. The maximum value of thermal stress in the blade equals only to $9.8 \mathrm{MPa}$.

7. Tetrahedral TET-4 finite elements are not good choice for modelling the disc and the blades of aero-engines. The results of the work [2] showed that better efficiency in modelling of the fir tree slots (smooth mesh at much smaller number of nodes and elements) can be obtained using hexagonal HEX-20 second order finite elements.

\section{Acknowledgement}

The research leading to these results has received funding from the People Programme (Marie Curie International Research Staff Exchange) of the European Union's Seventh Framework Programme FP7/2007-2013/ under REA grant: PIRSES-GA-2013610547.

\section{References}

[1] Meguid S.A., Kanth P.S., Czekanski A.: Finite element analysis of fir-tree region in turbine disc, Finite Element Analysis Design, 35 (2000) 305-317.

[2] Witek L.: Failure analysis of turbine disc of an aero engine, Eng. Failure Analysis, 13 (2006) 9-17.

[3] Witek L., Bednarz A., Stachowicz F.: Fatigue analysis of compressor blade with simulated foreign object damage, Eng. Failure Analysis, 58 (2015) 229-237.

[4] Chan S.K., Tuba I.S.: A finite element method for contact problems of solid bodies - Part II: Applications to turbine blade fastenings, Int. J. Mech. Sci., 13 (1971) 627-639.

[5] Masataka M. Root and groove contact analysis for steam turbine blades, JSME Int. J., 35 (1992) 508-514. 
[6] Papanikos P., Meguid S.A., Stjepanovic Z.: Three-dimensional nonlinear finite element analysis of dovetail joints in aero-engine discs, Finite Element Analysis Design, 29 (1998) 173-86.

[7] MSC-Patran 2009 Users Manual, MSC Corporation, Los Angeles, 2009.

[8] ABAQUS ver. 6.9 Users Manual, Abaqus Inc., 2009.

[9] Michailov P.B.: Sprawocznik po metaliczeskim matierialam turbino i motorostroenija, Petersburg 1961 (in Russian).

[10] Kowalski T., Mamrowicz J. Witek L.: Numerical stress and fatigue analysis of the first stage power turbine for helicopter engine, Proc. 24th Int. Committee on Aeronautical Fatigue (ICAF) Symposium, Napoli, Italy, 2007.

[11] Zboiński G., Ostachowicz W.: A general FE computer program for 3D incremental analysis of frictional contact problems of elastoplasticity, Finite Elements Analysis Design, 27 (1997) 307-322.

[12] Park M., Hwang Y., Choi Y., Kim T.: Analysis of a J69-T-25 engine turbine blade fracture, Eng. Failure Analysis, 9 (2002) 593-601.

[13] Song W., Keane A., Rees J., Bhaskar A., Bagnall S.: Turbine blade fir-tree root design optimisation using intelligent $\mathrm{CAD}$ and finite element analysis, Computers Structures, 80 (2002) 1853-1867.

\section{ANALIZA NAPRĘŻEŃ TERMO-MECHANICZNYCH TURBINY SILNIKA ŚMIGŁOWCOWEGO}

\section{Streszczenie}

Praca przedstawia wyniki numerycznej analizy naprężeń turbiny napędowej silnika śmigłowcowego. Do rozwiązania problemu wykorzystano metodę elementów skończonych. Modele numeryczne łopatki oraz segmentu tarczy wykonano korzystając z programu MSC-Patran. $\mathrm{W}$ analizie zdefiniowano obciążenie cieplne wynikające z niejednorodnego rozkładu temperatury. Dodatkowo zdefiniowano siłę odśrodkową elementów wynikającą z obrotu wirnika silnika. W celu ograniczenia wymiaru zadania numerycznego do segmentu tarczy zastosowano warunek brzegowy w postaci symetrii cyklicznej. Model materiału turbiny zdefiniowano jako liniowosprężysty. W analizie uwzględniono dodatkowo zmianę wartości modułu Younga oraz współczynnika rozszerzalności termicznej materiału w funkcji temperatury. W rezultacie przeprowadzonych obliczeń określono rozkład naprężeń turbiny poddanej działaniu złożonego obciążenia termo-mechanicznego.

Słowa kluczowe: silnik lotniczy, łopatka turbiny, tarcza wirnika, analiza naprężeń termomechanicznych, metoda elementów skończonych

DOI: $10.7862 / \mathrm{rm} .2016 .31$

Otrzymano/received: $11.10 .2016 \mathrm{r}$.

Zaakceptowanolaccepted: 28.11.2016r. 